\title{
The productivity in the beekeeping sector of Comalcalco, Tabasco, for the design of an improvement proposal
}

\section{La productividad en el sector apícola del municipio Comalcalco, Tabasco, para el diseño de una propuesta de mejora}

PAYRÓ-GARCÍA, Génesis $\dagger^{\prime}$, MOREJON-SANCHEZ, Juana María', PAYRÓ-DE LA CRUZ, Emeterio*" and MONTEJO-ZAMUDIO, Manuela de Jesús'

'Tecnológico Nacional de México, Campus Villahermosa, México.

"Tecnológico Nacional de México, Campus Zona Olmeca, México.

ID $1^{\text {st }}$ Author: Génesis, Payró-García / ORC ID: 0000-0002-7705- 0028 - Researcher ID Thomson: ABE-2833-2020, CVU CONACYT ID: 1003690

ID $1^{\text {st }}$ Co-author: Juana María, Morejón-Sánchez / ORC ID: 0000-0002-9930-181X, Researcher ID Thomson: ABE-28792020, CVU CONACYT ID: 362413

ID $2^{\text {nd }}$ Co-author: Emeterio, Payró-De la Cruz / ORC ID: 0000-0001-9970-6561, Researcher ID Thomson: AAY-92072021, CVU CONACYT ID: 78007

ID $3^{\text {rd }}$ Co-author: Manuela de Jesús, Montejo-Zamudio / ORC ID: 0000-0002-6523-7231, Researcher ID Thomson: AAW2648-2021, CVU CONACYT ID: 1003683

DOI: $10.35429 / E J R N .2021 .13 .7 .28 .32$

Received July 25, 2021; Accepted December 30, 2021

\section{Abstract}

The objective of this research was to analyze the productivity of the beekeeping sector of the municipality of Comalcalco, Tabasco for the design of an improvement proposal, which was approached by studying the behavior of the context variables (environmental, cultural, economic, political, social and technological) and its influence on the dependent variable, (productivity). For this, a design of the Likert scale tool was carried out, which is composed of sections that include the context variables, through this tool the results were analyzed, then SWOT matrices (Strengths, Weaknesses, Opportunities, Threats) were generated. for each context variable, from which the following improvement proposals were obtained according to each variable respectively; characterize natural flowering, foster a business culture, create income control, manage political support, disseminate the benefits of bees to eradicate fear from society, and manage genetic improvement programs.

\begin{abstract}
Resumen
El objetivo de la presente investigación fue analizar la productividad del sector apícola del municipio de Comalcalco, Tabasco para el diseño de una propuesta de mejora, lo cual se abordó mediante el estudio del comportamiento de las variables del contexto (ambiental, cultural, económica, política, social y tecnológica) y su influencia sobre la variable dependiente, (la productividad). Para ello se realizó un diseño de la herramienta escala de Likert, el cual se compone por secciones que incluyen las variables del contexto, a través de esta herramienta se analizaron los resultados, posteriormente se generaron matrices FODA (Fortalezas, Oportunidades, Debilidades, Amenazas) para cada variable del contexto, de lo cual se obtuvieron las siguientes propuestas de mejora de acuerdo a cada variable respectivamente; caracterizar la floración natural, fomentar una cultura empresarial, creación de un control de ingresos, gestion de apoyos políticos, difusion de las bondades de las abejas para erradicar el temor de la sociedad y gestión de programas de mejoramiento genético.
\end{abstract}

Productividad, Apícola, Variable

Citation: PAYRÓ-GARCÍA, Génesis, MOREJON-SANCHEZ, Juana María, PAYRÓ-DE LA CRUZ, Emeterio and MONTEJO-ZAMUDIO, Manuela de Jesús. The productivity in the beekeeping sector of Comalcalco, Tabasco, for the design of an improvement proposal. ECORFAN Journal-Republic of Nicaragua. 2021. 7-13:28-32.

\footnotetext{
* Correspondence to Author (Email: emeterio.pd@zolmeca.tecnm.mx)

$\uparrow$ Researcher contributing first author.
} 


\section{Introduction}

In recent years, companies have largely focused their attention on the productivity indicators they possess, since productivity is the means by which the company's performance can be identified, that is, if the resources with what Whether human, material, equipment, technological, energy or financial resources, to mention just a few, they are used effectively and efficiently. Productivity in Latin America is a very broad topic to deal with because in this part of the world since past decades it has remained with a lack of increase in its productivity levels, growth has been extremely slow and minimal, despite the Different changes of government that have occurred over time have not reflected relevant changes, this is a great sign that neither the necessary actions nor the interest are carried out to generate a positive change in this regard. In the study of productivity it is mentioned that beekeeping can be considered as a business opportunity, as long as profitability is guaranteed, looking for alternatives that allow increasing income through increased productivity and defining better market strategies, at their own expense. Once it is explained that one way to increase productivity is by promoting favorable changes in production levels, which is why it is important to identify the variables of the context that have had a positive impact, such as economic and cultural, which would allow the design of strengthening programs to improve this indicator (Contreras \& Magaña, 2017).

Mexico is the fourth producer and third exporter of honey in the world, according to SIAP-SAGARPA (2021), in 2018 36,068,281 tons were exported, in 2019 26,914,892 were exported and in 202023 were exported. 768,840 tons, which shows a downward trend in the last 3 years; however, it continues to be one of the livestock products that generate the most foreign exchange for our country. At the national level there are 2, 157, 866 beehives, of which 388, 433 are located in the state of Yucatán, 268, 907 in Campeche, 171, 822 in Chiapas, 141, 998 in Veracruz, with 11, 760 in Tabasco being one of the states with the lowest number of hives and as well as honey production, despite its great floristic potential.
Production is affected by a large number of factors, such as floral availability, environment, technical capacity, genetic quality of the bees and not least is the level of organization of the beekeepers. Guzmán-Novoa et al., (2002), demonstrated that both the capacity for honey production and the defensive behavior of bees are highly influenced by the genotype, concluding that the defensiveness of Africanized bees is a highly heritable characteristic; however, there is little research aimed at understanding the genetic bases of this behavior and its correlation with productivity.

Currently there are controversies regarding whether or not hybrid (Africanized) bees are more efficient in honey production compared to European bees, however, UribeRubio et al, (2003), affirm that this controversy is caused by that few comparative studies have been carried out and the lack of representativeness in the experiments carried out.

It is essential to consider that highly defensive behavior is the most undesirable character of Africanized bees, however, there are equipment, techniques and safety measures to work with bees safely, however, production costs and production costs are significantly increased. the number of hives that a beekeeper can attend per working day decreases (GuzmánNovoa et al., 1994). It is worth mentioning that bees, in addition to all the products they generate, also through their sting provide health benefits to people, and many times it is used as an alternative medicine to combat different diseases, it must be recognized that beekeeping is a noble activity, which leaves a great imprint of learning of perseverance, perseverance and many other benefits in the people who exercise it, and provides economic, environmental and social benefits.

The Inter-American Development Bank (IDB), an institution that has different financing programs in charge of benefiting countries that wish to increase their economic development, either through donations or through loans; the donations that are made can be to both private and public entities, both participate and can benefit, however this institution mentions that América Lantina presents a slow chronic growth that has persecuted it for years, this due to the productive resources with which account are used without proper planning. 
Currently, the amount of financing approved for Mexico is $\$ 825.80 \mathrm{M}$, leveraging six productive sectors, which are financial markets, science and technology, education, energy, social investments, environment and natural disasters. Likewise, according to IDB (2021), the low level of productivity is the primary cause why a large number of the countries belonging to Latin America fail to achieve a higher level of growth, since they lag behind in comparison. of the countries belonging to East Asia and in the same way to the countries that are advanced, if a country increases its productivity all its inhabitants will be benefited since they entail great monetary and service gains.

\section{Kind of investigation}

Due to the resources that are currently available, the municipality of Comalcalco was selected, since there is previous knowledge regarding producers and location of apiaries for the startup, all the information collected was taken as a basis for the generation of a improvement proposal that contributes to increasing productivity and therefore the regional development of this sector. The investigation on the beekeeping sector is documentary, because information was obtained from different secondary sources, in turn, a field investigation was carried out obtaining information directly from the producers. At another time it is descriptive because each one of the study variables is described. At another moment the research is considered correlational, because it determines how each of the independent variables (social, cultural, environmental, political, technological, economic) influences the research variable (productivity of the beekeeping sector).

\section{Methodology to be developed}

The methodology used for the present investigation is based on the identification of the problem as a starting point, subsequently the variables of the context to be analyzed were identified and the Likert scale tool was designed to collect the information. directly with the beekeepers of the municipality, through meetings and interviews with the beekeepers as well as visits to the apiaries, which were georeferenced, for the elaboration of a map in order to know the territorial distribution of the production properties in the municipality of Comalcalco (Figure 1).
It is worth mentioning that the tool includes each of the variables, as well as items [environmental (items $=15$ ), economic (items $=$ 21), political (items $=7$ ), social $($ items $=9$ ) and technological (items $=26$ ) ], which are closely related to the dependent variable (productivity), it is important to mention that the tool was applied personally to beekeepers and a detailed explanation of the meaning of each of the items that make up the tool was provided to them, in order to In this way to ensure the veracity of the information provided, once the tool was applied, the interpretation and analysis of the results was carried out, consequently a SWOT matrix was made for each of the variables, within which the strengths, opportunities, weaknesses, threats, which will make it possible to develop comprehensively and efficiently improvement strategies that will bring positive aspects in terms of productivity to the sector.

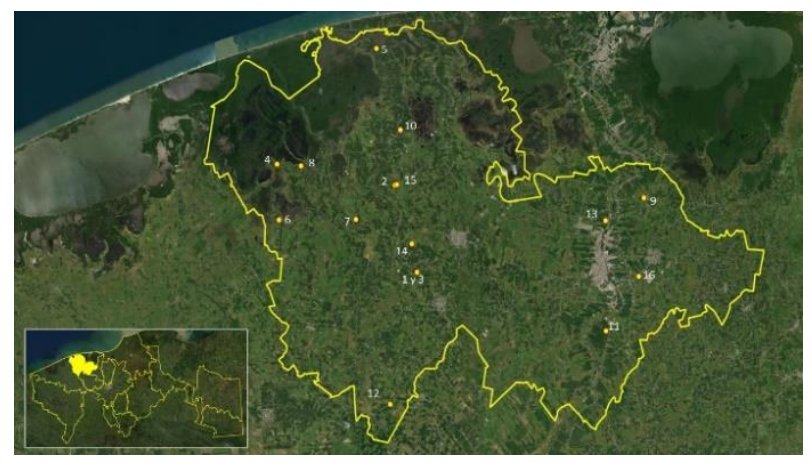

Figure 1 Territorial distribution of the apiaries of the surveyed beekeepers, (ID): 1. José Alfredo Aguilar Sánchez, 2. Alejandro Jiménez Hernández, 3. Bella Ruth Hernández Hernández, 4. David Calderón Alvarado, 5. Rene Alejandro Alejandro, 6. Manolo Castillo Arévalo, 7. Teresa Alejandro Carrillo, 8. Sebastián Córdova Arévalos, 9. Julio Cesar Diaz Méndez, 10. José Luis Sánchez Izquierdo, 11. Heriberto Alejandro Romero, 12. Luis Mario Córdova Madrigal, 13. Virginia Falconi Alejandro, 14. Cristóbal Izquierdo Alcocer, 15. Sebastián Rodríguez Córdova, 16. Mario Pérez Córdova. Sources: Apiaries georeferenced by the author. Made with QGIS software. Scale 1: 200,000. ESRI Satellite

\section{Results}

According to the results obtained through the Likert scale, six SWOT martices were elaborated, one for each context variable, as shown in Figures 2 to 7, respectively: 


\begin{tabular}{|l|l|}
\hline \multicolumn{2}{|c|}{ SWOT } \\
\hline \multicolumn{2}{|c|}{ ENVIRONMENTAL VARIABLE } \\
\hline $\begin{array}{l}\text { THREATS } \\
\text { Climate change }\end{array}$ & $\begin{array}{l}\text { STRENGTHS } \\
\text { Identification of the time } \\
\text { of greatest flowering in } \\
\text { the year, which are the } \\
\text { months of January, } \\
\text { February and March. }\end{array}$ \\
\hline $\begin{array}{l}\text { WEAKNESSES } \\
\text { Mobilization of hives due } \\
\text { to flooding }\end{array}$ & $\begin{array}{l}\text { OPPORTUNITIES } \\
\text { Characteristics of the } \\
\text { flowering that surrounds } \\
\text { the apiaries is optimal }\end{array}$ \\
\hline
\end{tabular}

Figure 2 SWOT of the environmental variable Source: Author's Perception, 2021

\begin{tabular}{|l|l|}
\hline \multicolumn{2}{|c|}{ SWOT } \\
\hline \multicolumn{1}{|c|}{ CULTURAL VARIABLE } \\
\hline THREATS cultic cultural changes & $\begin{array}{l}\text { STRENGTHS } \\
\text { Current culture and } \\
\text { traditions help to carry out } \\
\text { beekeeping activities }\end{array}$ \\
\hline $\begin{array}{l}\text { WEAKNESSES } \\
\text { Lack of corporate culture }\end{array}$ & $\begin{array}{l}\text { OPPORTUNITIES } \\
\text { Opening receive training } \\
\text { to identify and treat } \\
\text { diseases }\end{array}$ \\
\hline
\end{tabular}

Figure 3 SWOT of the cultural variable

Source: Author's Perception, 2021

\begin{tabular}{|l|l|}
\hline \multicolumn{2}{|c|}{ SWOT } \\
\hline \multicolumn{2}{|c|}{ ECONOMIC VARIABLE } \\
\hline $\begin{array}{l}\text { THREATS } \\
\text { Lack of financial support } \\
\text { from the government and } \\
\text { private organizations }\end{array}$ & $\begin{array}{l}\text { Starting your micro } \\
\text { business with your own } \\
\text { financial resources }\end{array}$ \\
\hline $\begin{array}{l}\text { WEAKNESSES } \\
\text { No own vehicle to get to } \\
\text { the apiaries }\end{array}$ & $\begin{array}{l}\text { OPPORTUNITIES } \\
\text { Promotion of income and } \\
\text { expenditure control }\end{array}$ \\
\hline
\end{tabular}

Figure 4 SWOT of the economic variable Source: Author's Perception, 2021

\begin{tabular}{|c|c|}
\hline \multicolumn{2}{|c|}{ SWOT } \\
\hline \multicolumn{2}{|c|}{ POLICY VARIABLE } \\
\hline $\begin{array}{l}\text { THREATS } \\
\text { The requirements that the } \\
\text { city council asks for to } \\
\text { formalize its micro } \\
\text { enterprises are many }\end{array}$ & $\begin{array}{l}\text { STRENGTHS } \\
\text { Members of the honey } \\
\text { safety and traceability } \\
\text { program }\end{array}$ \\
\hline $\begin{array}{l}\text { WEAKNESSES } \\
\text { Lack of application of the } \\
\text { manual of good practices }\end{array}$ & $\begin{array}{l}\text { OPPORTUNITIES } \\
\text { They have the support of } \\
\text { the city council of the } \\
\text { municipality }\end{array}$ \\
\hline
\end{tabular}

Figure 5 SWOT of the political variable

Source: Author's Perception, 2021

\begin{tabular}{|l|l|}
\hline \multicolumn{2}{|c|}{ SWOT } \\
\hline \multicolumn{2}{|c|}{ SOCIAL VARIABLE } \\
\hline $\begin{array}{l}\text { THREATS damaged } \\
\begin{array}{l}\text { Beehives } \\
\text { because of people's fear }\end{array}\end{array}$ & $\begin{array}{l}\text { STRENGTHS } \\
\text { Closeness to customers } \\
\text { allows them to know their } \\
\text { preferences }\end{array}$ \\
\hline $\begin{array}{l}\text { WEAKNESSES } \\
\begin{array}{l}\text { Lack of trust in their } \\
\text { micro businesses }\end{array}\end{array}$ & $\begin{array}{l}\text { OPPORTUNITIES } \\
\text { Customers' preference to } \\
\text { buy in artisan shops }\end{array}$ \\
\hline
\end{tabular}

Figure 6 SWOT of the social variable Source: Author's Perception, 2021

\begin{tabular}{|c|l|}
\hline \multicolumn{2}{|c|}{ SWOT } \\
\hline \multicolumn{1}{|c|}{ TECHNOLOGICAL VARIABLE } \\
\hline $\begin{array}{l}\text { THREATS } \\
\text { They do not have a good } \\
\text { internet signal }\end{array}$ & $\begin{array}{l}\text { STRENGTHS } \\
\text { It has materials and } \\
\text { equipment to perform } \\
\text { extraction, which reduces } \\
\text { waste. }\end{array}$ \\
\hline $\begin{array}{l}\text { WEAKNESSES } \\
\text { They do not have an } \\
\text { extraction room }\end{array}$ & $\begin{array}{l}\text { OPPORTUNITIES } \\
\text { Website creation }\end{array}$ \\
\hline
\end{tabular}

Figure 7 SWOT of the technological variable Source: Author's Perception, 2021

\section{Conclusions}

The conclusions are presented for each variable of the context: 1.- Environmental: Characterize the natural flowering and promote plantings of nectar pollinifera species, as well as implement strategies for the protection of hives in times of flooding. 2.- Cultural: Promote a business culture in beekeepers, which will help them to have a better vision of their production. 3.Economic: Promotion of income control, as well as the selection of points of sale strategically, registration of brands and labels. 4.- Policy: Adopt good honey production practices, streamline registration procedures that allow government support to be managed. 5.- Social: Promote awareness programs of the benefits of bees for the environment that allow eradicating the fear that society feels towards bees. 6.Technological: Promote genetic selection and improvement programs from bees adapted to local environmental conditions that favor the annual change of queen bees with surveillance of pests and diseases, as well as the acquisition of equipment for the extraction of honey in attachment to food safety standards. It is estimated that within a year favorable results will be achieved for each of the context variables, which can be evaluated at the end of the next harvest. 


\section{Thanks}

To the Municipal Development Directorate of the Comalcalco City Council, Tabasco, for the logistical support in carrying out the meetings and field visits for the interviews and application of the surveys.

To the United Beekeepers of Comalcalco for their kind collaboration.

\section{References}

BID (2021). Perspectiva general. Banco Interamericano de Desarrollo. https://www.iadb.org/es/paises/mexico/perspect iva-general

Contreras, L. C., \& Magaña, M. A. (2017). Costos y rentabilidad de la apicultura a pequeña escala en comunidades mayas del Litoral Centro de Yucatán, México. Investigación y Ciencia, 25(71), 52-58.

Guzman-Novoa, E., Hunt, G.J., Uribe, J.L., Smith, C., y Arechavaleta, V.M.E. (2002). Confirmation of QTL effects and evidence of genetic dominance of honey bee defensive behavior: Results of colony and individual behavioral assays. Behav. Genet. 32: 95-102.

Guzman-Novoa, E., Page R.E., y Fondrk, M.K. (1994). Morphometric techniques do not detect intermediate and low levels of africanization in honney bee (Apis mellifera) colonies. Ann. Entomol. Soc. Am. 87: 507-515.

SIAP-SAGARPA (2021). Servicio de información y estadística agroalimentaria (SIAP)

http://infosiap.siap.gob.mx/repoAvance_siap_g b/pecResume.jsp

Uribe-Rubio, J.L., Guzman-Novoa, E., Hunt, G.J., Correa-Benitez A., y Zozaya, J.A. (2003). Efecto de la africanización sobre la producción de miel, comportamiento defensivo y tamaño de las abejas melíferas (Apis mellifera) en el altiplano mexicano. Vet. Mex. 34(1): 47-59. 